\title{
GROWTH EFFECTS OF FOREIGN DIRECT INVESTMENT AND FINANCIAL DEEPENING IN NIGERIA (1981-2018)
}

\author{
Gbenga F. BABARINDE \\ Modibbo Adama University of Technology, Yola, Nigeria \\ liftedfgb@gmail.com
}

\begin{abstract}
This study investigates growth effects of foreign direct investment and financial deepening in Nigeria for the period 1981-2018. Data employed for this study were obtained from Central Bank of Nigeria Statistical Bulletin and World Development Indicators. Pairwise granger causality test and autoregressive distributed lag (ARDL) model were employed in the data analysis. Empirical results show that foreign direct investment (FDI) has positive significant effect on economic growth (GDP) in Nigeria both in the long and short runs. Financial deepening measured as broad money supply as a ratio of GDP (broad money velocity) has positive significant effect on GDP in Nigeria in the long run but the position is reversed to negative non-significant in the short run. In the long run, financial deepening indicator-credit to private sector as a ratio of GDP-, has negative non-significant effect on GDP in Nigeria while its influence is absent in the short run model. Findings also reveal a unidirectional causality from FDI to GDP. Likewise, unidirectional causality flows from GDP to each of the two financial deepening indicators, thus lending credence to the demand-following hypothesis. This study concludes that foreign direct investment and financial deepening have positive growth effects in Nigeria with causality flowing from foreign direct investment to economic growth and the latter granger-causing financial deepening in Nigeria. To boost economic growth, there is a need for Nigeria's government to further develop the financial system and implement policies to stimulate FDI inflows to the country.
\end{abstract}

Keywords: ARDL, Economic growth, Foreign direct investment, Financial deepening, Granger causality.

\section{INTRODUCTION}

Economic growth is a coveted aim of any developing country and therefore every sector, real and financial, is expected to contribute its quota to the lofty objective. The Nigerian financial sector, though bank-based, still the stock-market is perceived to also constitute one of the conduit pipes to develop the economy. Developing countries like Nigeria have been attracting foreign direct investment (FDI) in the recent times. FDI is essential in that it brings in technology, knowledge transfers for managerial skills, and human capital to come into the host country. Yusuf et al. (2020) argue that FDI as a conduit pipe for technology and knowledge transfers, lead to increasing returns to production as a result of productive 
spillovers, which stimulate economic growth of the host countries. This implies that inflow of FDI have the potential to encourage the growth of the economy of the host countries.

The development of the financial services industry ensures, through financial intermediation process, that savings, credit and funds are mobilized for trade and investment purposes which ultimately spur real sector activities. As a form of financial development, financial deepening (FINDEP) ensures wider consumers of financial products and services are reached with ease, economy and speed with their desired requirements at all strata of the society. FINDEP is indicated by a higher ratio of different financial services provision indicators, such as money supply, stock market capitalization, credit to private sector, insurance sector services, mortgage services, etc., to the gross domestic growth (GDP). Generally, the financial sector is expected through its financial intermediation functions, to promote economic growth by increasing economic efficiency, investment and financial deepening.

Empirically, there are avalanche of studies linking FDI and economic growth and those that separately examined the response of the latter to financial deepening indicators. Except for few studies indicating otherwise, most past studies found evidence of a positive relationship between FDI and GDP when examined separately. This same result is also found in case financial deepening-growth nexus studies. There are, however, relatively scanty empirics on FDI-FINDEP-GDP in developing country like Nigeria. Will the FDI and financial deepening be positively signed with GDP if examined within FDI-FINDEPGDP nexus framework? The few studies available empirical evidence on the effect of both foreign direct investment and financial deepening on economic growth have been divergent. Some indicate that FDI and FINDEP are positively signed with GDP (Alabi et al. (2018), Sharmiladevi (2015), Yusuf et al. (2020)) while others are divided between positively and negatively signed with GDP (Oniore, 2014). This study is motivated by this lacuna in literature and mixed findings reported by the relatively few studies on the subject matter. Therefore, this study investigates growth effects of foreign direct investment and financial deepening indicators in Nigeria for the period 1981-2018 using the autoregressive distributed lag (ARDL) model and pairwise Granger causality technique.

\subsection{Objectives of the Study}

The main objective of this study is to analyze the effects of foreign direct investment and financial deepening indicators on economic growth in Nigeria for the period 1981 to 2018. The specific objectives are:

i. To determine the economic growth effects of foreign direct investment (FDII in Nigeria;

ii. To examine the effect of financial deepening indicator-credit to private sector as a ratio of gross domestic product (GDP), on economic growth in Nigeria; 
iii. To evaluate the effect of financial deepening indicator-broad money supply as a ratio of GDP (broad money velocity), on economic growth in Nigeria;

iv. To assess the direction of causality between FDI and economic growth in Nigeria;

v. To analyse the direction of causality between credit to private sector as a ratio of GDP and economic growth in Nigeria;

vi. To ascertain the direction of causality between broad money velocity and economic growth in Nigeria.

\subsection{Hypotheses of the Study}

The study hypothesizes are as follows:

$\mathrm{HO}_{1}$ : FDI does not have significant positive effect on economic growth in Nigeria;

$\mathrm{HO}_{2}$ : Financial deepening indicator-credit to private sector as a ratio of GDP, does not have significant positive effect on economic growth in Nigeria;

$\mathrm{HO}_{3}$ : Broad money velocity does not have significant positive effect on economic growth in Nigeria;

$\mathrm{HO}_{4}$ : There is no causality between FDI and economic growth in Nigeria;

HO5: There is no causality between credit to private sector as a ratio of GDP and economic growth in Nigeria; and

$\mathrm{HO}_{6}$ : There is no causality between broad money velocity and economic growth in Nigeria.

The rest of this paper is organized thus. Section 2 reviews the literature on foreign direct investment, financial deepening and their role in the growth process. Section 3 describes the data, model specification and estimation techniques. Section 4 reports the empirical analysis and results as well as discussion of findings. Finally, section 5 concludes the paper and gives some policy recommendations.

\section{LITERATURE REVIEW}

\subsection{Conceptual Review}

Egbo et al. (2011) conceptualize foreign direct investment (FDI) to be an investment made to acquire lasting interest in enterprises operating outside the economy of the investor. It also refers to direct investment in production, business, program and organization in a country by foreign individual, company or government for the purpose of making or marketing products and services in a foreign country (Adeleke et al., 2014).

Financial deepening, which focuses more on the process of financial intermediation, refers to the expansion of the financial services to all levels of society in terms of depth. 
Economic growth is a sustained and persistent rise in the productive capacity of an economy, in terms of capital, trade volume, consumption, labor and ultimately reflecting in rise in Gross Domestic Product, gross national product.

\subsection{Theoretical Review}

There are several theories of growth focusing on the sources of the growth. For instance, the FDIgrowth-led hypothesis focuses on FDI inflows as a stimulant of economic growth in a country. The balanced growth theory is another theory which hypothesizes growth should be all-round, and the sources of the growth should also be multifaceted. Therefore, developing countries government should invest in several industries/sectors such as industrial, agricultural, manufacturing, concurrently as to stimulate balanced growth. This will enlarge the market size, increase productivity, and provide an incentive for the private sector to invest. Unlike the balanced growth theory, the unbalanced growth hypothesis posits that investment should be made in selective sectors rather than simultaneously in all sectors.

The supply-leading theory and demand-following hypothesis are other strands of theories. The supplyleading theory emphasizes that financial deepening leads to economic growth. This is based on the notion (Nwaolisa and Cyril (2018)), that financial markets stimulate a higher savings and investment, which enhance capital accumulation, transfer of resources from non-growth sectors to the productive growth-inducing sectors. This eventually, culminates in higher real sector growth. On the other hands, the demand-following theory argues otherwise that economic growth stimulates demand for financial services, thereby granger-causing financial sector development/deepening.

This study is theoretically underpinned by the demand-following hypothesis and supply-leading theory. This is because this study relates financial variables to real sector growth, thus investigating the role of financial development and foreign capital inflows in the economy of Nigeria.

\subsection{Empirical Review}

\subsubsection{Foreign Direct Investment and Economic Growth}

The results of studies carried out on the relationship between FDI and economic growth in Nigeria are not unanimous in their submissions. For example, Sokang (2018) from the investigation of the effect of FDI on the economic growth of Cambodia, found a positive and significant relationship between GDP and FDI. Most other international empirical evidence also affirms positive FDI-growth nexus in different countries (Chigbu et al. (2015) in Ghana and India; Ek (2007) in China; Jayaraman et al. (2017) in India; Kadiatou (2017) in Niger). In a similar study, Dinh et al. (2019) conclude that in developing countries of 
the lower-middle-income group, FDI capital flows endanger and promote country's economic growth in the short run and long run respectively.

Results of the causality test between FDI and GDP by Aderemi et al (2019) reveal a unidirectional causality runs from FDI to economic growth in selected West African and seven emerging countries respectively. Similarly, Jayaraman et al. (2017) concludes that in India a unidirectional causality running from FDI to output. However, Kadiatou (2017)'s findings reveal a bi-directional causality between FDI and GDP of Niger.

Alfaro et al. (2007) argue that increase in inflows of FDI spurs higher growth in financially developed economies than the financially under-developed ones. Various studies have indicated the positive role of foreign capital inflow in the economic fortune of African countries (Adegboye et al., 2020; Awolusi et al., 2016).

Although, country specific factors (Egbo et al., 2011) such as the policy choice shape the direction and potency of influence of foreign direct investment inflow on the host countries. However, previous empirical findings on FDI-growth nexus in Nigeria still produce mixed evidence, though most of them supporting the positive FDI-growth nexus in Nigeria. In their study, however, Adeniyi et al. (2012) found evidence of no short- or long-run causal flow from FDI to growth with financial deepening accompanying in Nigeria. In another studies, Okumoko et al (2018) conclude that FDI has a positive and insignificant effect on the growth of Nigerian economy.

Asogwa and Manasseh (2014) using disaggregated approach, found empirical evidence that FDI into manufacturing and telecommunication sectors has positive effect on economic growth in Nigeria while FDI into agricultural sector effected on economic growth negatively. Akanegbu and Chizea (2017) and also found FDI exerting positive significant effect on economic growth in Nigeria. Like Akanegbu and Chizea, most other studies found that FDI has significant positive effect on the growth of Nigerian economy (Adeleke et al. (2014); Adigwe et al (2015); Aguda and Oladoja (2017); Alabi (2019); Chigbu et al. (2015); Egbo, et al. (2011); Ovat and Amba (2018)). Unlike most studies, Nsofor and Takon (2017) conclude that foreign direct investment has negative non-significant effect on the Nigerian economic growth.

Furthermore, Okoye and Nwisienyi (2019) show that in the long-run, FDI has positive and significant impact on economic growth but statistically insignificant in the short-run. However, the FDI inflow has insignificant negative effect on the GDP in Nigeria. Ayanwale (2007) submits that although the overall effect of FDI on economic growth may not be significant, the components of FDI do have a positive effect. 
The causality between FDI and GDP of Nigeria investigated by Egbo, et al. (2011) found evidence of a unidirectional causality ran from FDIs to GDP. Okoye and Nwisienyi (2019) however, posit that there is no directional causality between the two variables in Nigeria.

\subsubsection{Financial Deepening and Economic Growth Nexus}

Ghildiyal et al. (2015) submit that financial deepening causes economic growth in the long and short runs in in India. In Taiwan, in short-run, economic growth has a significant and positive effect on financial deepening in the high-growth regime. Adan (2017) reveals that credit to the private sector (CPS) has positive and statistically significant effects on GDP of Kenya.

Alrabadi and Kharabsheh (2016) investigate the dynamic relationship between financial deepening and economic growth in Jordan. Their findings indicate no statistically significant effect of financial deepening on economic growth on the short run. However, Adeniyi et al. (2012) support the view that financial development is necessary for FDI to impact on economic growth positively in Ghana, Gambia and Sierra Leone.

Alrabadi and Kharabsheh (2016) established a bi-directional causality between economic growth and financial deepening indicator-CPS; but a unidirectional causality flowing from the economic growth to financial deepening indicator-broad money supply. Safdar (2014) in Pakistan shows an evidence of unidirectional relationship between FDI and GDP, inflation and GDP, FDI and inflation but there is no causal relationship among financial deepening and GDP and financial deepening and FDI. In a related, Gezer (2018) investigates the causal relationship between financial deepening and economic growth for fourteen upper middle-income countries. Gezer findings indicate that countries can be clustered according to supply-leading and demand following approach, with evidence of bidirectional causality for some countries.

Empirical study on the effect of financial deepening on economic growth in Nigeria by Torruam et al (2013) and Nwakobi et al. (2019) indicate a unidirectional causality running from economic growth to financial deepening in Nigeria. Nwaolisa and Cyril (2018) and Nwanna and Chinwudu (2016) also conclude that money supply and private sector credit have positive significant effect on economic growth in Nigeria. Likewise, Efanga et al. (2020), Kolawole et al. (2019) and Torruam et al (2013) indicate that financial deepening had positive effect on the Nigerian economy. Some studies reveal that in Nigeria, money supply is positive and weakly significant in determining economic growth. However, CPS was found by the author to be negative and non-significant in the short run.

Moreover, Onwumere et al. (2012) found that broad money velocity has a positive non- significant effect on GDP rate in Nigeria. Also, credit to the private sector/GDP, has a negative non-significant effect on GDP rate in Nigeria. Karimo and Ogbonna (2017)'s results follow the supply-leading hypothesis of 
financial deepening causing growth in Nigeria. Yahaya and Kolapo (2017)'s findings reveal that banking sector and capital market related financial deepening variables are significant determinants of economic growth in Nigeria. Moreover, Alenoghena (2014) reveal that broad money as a ratio of GDP and CPS has positive and negative effect respectively, on economic growth but both are not significant in explaining the trend in economic growth in Nigeria.

\subsubsection{Financial Deepening, Foreign Direct Investment and Economic Growth Interaction}

Sghaier and Abida (2013) examine the causal linkage between FDI, financial development and economic growth of Tunisia, Morocco, Algeria and Egypt. They find strong evidence of a positive relationship between $\mathrm{FDI}$ and economic growth. The authors also observe that the development of the domestic financial system is an important prerequisite for FDI to have a positive effect on economic growth.

Sharmiladevi (2015) examines the relationship between financial deepening, FDI and economic growth for India. The study found a strong positive correlation between the variables. Adeniyi et al. (2015) investigated financial development, FDI and economic growth nexus in selected Sub-Saharan Africa countries. The study shows a positive influence of FDI on economic growth. Financial development was also found by Adeniyi et al. to promote growth in the presence of FDI flows. Yusuf et al. (2020) examine the role of financial development, FDI, democracy and political instability on economic growth in West Africa. The authors suggest that no significant relationship is established in the short run, but in the long-run, FDI has positive significant on economic growth with financial development-growth nexus affirming the supply-leading hypothesis in West Africa.

Oniore (2014) also concluded that private sector credit, liquidity ratio and foreign direct investment have a statistically significant influence on Nigerian economic growth. However, the ratio of broad Money to GDP exerts a negative effect on economic growth. It is observed a negative relationship existed between financial market development and FDI in the long run while in the short run, a positive relationship existed between financial market development and FDI in Nigeria. Alabi et al. (2018) also submit that FDI and market capitalization as a percentage of the GDP exerted significantly on output performance both in the short-run and in the long-run periods in Nigeria.

In Nigeria a unidirectional causal relationship is established that flows from financial development (measured as the ratio of currency outside banks to money supply) to economic growth. The study further found evidence the financial development and FDI have negative individually but their joint effect is positive on economic growth in Nigeria.

In another study, Adegboyega and Odusanya (2014) examine the nexus between trade openness, FDI, capital formation, and economic growth rate in Nigeria. The study shows a significant positive effect 
Babarinde, G.F.

\section{GROWTH EFFECTS OF FOREIGN DIRECT INVESTMENT AND FINANCIAL DEEPENING IN NIGERIA (1981-2018)}

between the degree of trade openness, level of capital formation while a positive but insignificant relationship exist between the volume of FDI and GDP rate.

In summary, studies investigating the effects of both FDI and financial deepening on economic growth in Nigeria are still scanty. Although individual effects of each of the two variables have been examined by many scholars, which most past results show for each, are positively related to economic growth. This notwithstanding, this suggest that there exists a debate on whether the same position still holds when both variables are implemented together in an economy. This study is a contribution to knowledge on FDI-financial deepening-growth nexus in Nigeria.

\section{DATA, MODEL SPECIFICATION AND ESTIMATION TECHNIQUES}

\subsection{Data}

The study is based secondary annual time series data obtained from World Development Indicators (WDI) and Central bank of Nigeria's statistical bulletin (CBN) for the period 1981-2018. The data is fully described in table 1. In the table, while GDP constitutes the dependent variables, other variables are the explanatory variables.

TABLE 1. DATA DESCRIPTION

\begin{tabular}{|c|c|c|}
\hline Data & Definition & Measurement \\
\hline $\begin{array}{l}\text { Economic growth: } \\
\text { GDP }\end{array}$ & $\begin{array}{l}\text { Gross domestic product that is inflation-discounted, denominated in billion Naira } \\
\text { (Adegboyega and Odusanya (2014); }\end{array}$ & Estimate \\
\hline $\begin{array}{l}\text { Foreign direct } \\
\text { investment: FDI }\end{array}$ & $\begin{array}{l}\text { The net inflow of investment to acquire a lasting management interest }(10 \% \text { or } \\
\text { more of voting stock) in an enterprise operating in the recipient economy } \\
\text { (Adeniyi et al., 2015), Adegboye et al (2020) }\end{array}$ & $\%$ GDP \\
\hline $\begin{array}{l}\text { broad money } \\
\text { velocity: BMV }\end{array}$ & $\begin{array}{l}\text { Currency plus demand and interest-bearing liabilities of financial intermediaries } \\
\text { and non-bank financial institution (Adeniyi et al., 2015)., Alenoghena (2014), } \\
\text { (Onwumere, et. al., 2012). }\end{array}$ & $\%$ GDP \\
\hline $\begin{array}{l}\text { Credit to private } \\
\text { sector: CPSG }\end{array}$ & $\begin{array}{l}\text { Credit to private sector: The value of credits by financial intermediaries to the } \\
\text { private sector (Adeniyi et al., 2015), Alenoghena (2014). }\end{array}$ & $\%$ GDP \\
\hline Inflation: INFR & Annual percentage of consumer price indices & Estimate \\
\hline $\begin{array}{l}\text { Error correction } \\
\text { term: ECT }\end{array}$ & $\begin{array}{l}\text { It is the rate or speed of adjustment of previous period's disturbances to restore } \\
\text { the long run equilibrium }\end{array}$ & Estimate \\
\hline \multicolumn{3}{|c|}{ Source: Author's desk research output } \\
\hline \multicolumn{3}{|c|}{ 3.2 Model Specification and Estimation Techniques } \\
\hline \multicolumn{3}{|c|}{$\begin{array}{l}\text { Econometric techniques and models are employed in the analysis of data in this study. After descriptive } \\
\text { statistics, the study via both augmented Dickey-Fuller (ADF) and Phillips-Perron (PP) unit root tests, are }\end{array}$} \\
\hline 56 & & \\
\hline
\end{tabular}


applied to test the stationarity of each variable to avoid the incursion of spurious regression results. Then, the variables are also tested for any evidence of long run relationship among them via the autoregressive distributed lag (ARDL) F-Bounds co-integration test. The direction of causality between the variables is determined via the pairwise granger causality test. The ARDL approach was adopted to determine both the long run and short run estimates of the effect of foreign direct investment and financial deepening on economic growth in Nigeria. This study adopted ARDL approach because it most suitable estimator of data which are of different orders of integration. It is also suitable for estimating both short run and long run co-integrating variables.

\subsubsection{The Pairwise Granger Causality Model}

The pairwise granger causality test equations are specified in equations 1 to 4 .

$$
\begin{aligned}
& G D P_{\mathrm{t}}=\sum_{j=1}^{n} \alpha_{1} F D I_{t-\mathrm{i}}+\sum_{j=0}^{n} \alpha_{2} B M V_{\mathrm{t}-J}+\sum_{j=0}^{n} \alpha_{2} C P S G_{\mathrm{t}-\mathrm{k}}+\sum_{j=0}^{n} \alpha_{4} I N F R_{\mathrm{t}-1}+e_{1 \mathrm{t}} \\
& F D I_{\mathrm{t}}=\sum_{j=1}^{n} \beta_{1} G D P_{\mathrm{t}-\mathrm{i}}+\sum_{j=0}^{n} \beta_{2} B M V_{\mathrm{t}-J}+\sum_{j=0}^{n} \beta_{2} C P S G_{\mathrm{t}-\mathrm{k}}+\sum_{j=0}^{n} \beta_{4} I N F R_{\mathrm{t}-1}+e_{2 \mathrm{t}} \\
& B M V_{\mathrm{t}}=\sum_{j=1}^{n} y_{1} G D P_{t-i}+\sum_{j=0}^{n} y_{2} F D I_{t-I}+\sum_{j=0}^{n} y_{a} C P S G_{t-k}+\sum_{j=0}^{n} y_{a} I N F R_{t-1}+e_{a t} \\
& \text { CPSG }_{\mathrm{t}}=\sum_{j=1}^{n} \mathbb{Y}_{1} G D P_{\mathrm{t}-\mathrm{i}}+\sum_{j=0}^{n} \mathbb{Y}_{2} F D I_{\mathrm{t}-J}+\sum_{j=0}^{n} \mathbb{Y}_{\mathrm{a}} B M V_{\mathrm{t}-\mathrm{k}}+\sum_{j=0}^{n} \mathbb{Y}_{\mathrm{a}} I N F R_{\mathrm{t}-\mathrm{I}}+e_{4 \mathrm{t}}
\end{aligned}
$$

Where $e_{1 \mathrm{t}}, e_{2 \mathrm{t}}, e_{\mathrm{at}}$, and $e_{4 \mathrm{t}}$ are assumed to be uncorrelated.

\subsubsection{ARDL Long Run Equation}

The long run relationship among foreign direct investment, financial deepening and economic growth in Nigeria is stated within ARDL model framework as under (5).

$$
\begin{aligned}
\Delta G D P_{\mathrm{t}}=\alpha_{0}+ & \sum_{j=1}^{n} \beta_{1 j} \Delta G D P_{\mathrm{t}-j}+\sum_{j=0}^{n} \beta_{2 j} \Delta F D I_{\mathrm{t}-j}+\sum_{j=0}^{n} \beta_{a j} \Delta B M V_{\mathrm{t}-j}+\sum_{j=0}^{n} \beta_{4 j} \Delta C P S G_{\mathrm{t}-j} \\
& +\sum_{j=0}^{n} \beta_{5 j} \Delta I N F R_{\mathrm{t}-j}+\Psi_{1 j} G D P_{\mathrm{t}-1}+\Psi_{2 j} F D I_{\mathrm{t}-1}+\Psi_{a j} B M V_{\mathrm{t}-1}+\Psi_{4 j} C P S G_{\mathrm{t}-1} \\
& +\Psi_{5 j} I N F R_{\mathrm{t}-1}+U_{\mathrm{t}}
\end{aligned}
$$

A priori expectation: $\beta_{1 j}-\beta_{4 j}>0 ; \Psi_{1 j}-\Psi_{4 j}>0 ; \beta_{5 j}<0 \Psi_{5 j}<0$ 


\section{GROWTH EFFECTS OF FOREIGN DIRECT INVESTMENT AND FINANCIAL DEEPENING IN NIGERIA (1981-2018)}

\subsubsection{ARDL Short Run and Error Correction Model}

To estimate the short run coefficients and error correction term, the equation 6 below is specified and estimated.

$$
\begin{gathered}
\Delta G D P_{\mathrm{t}}=\alpha_{0}+\sum_{j=1}^{n} \beta_{1 j} \Delta G D P_{\mathrm{t}-j}+\sum_{j=0}^{n} \beta_{2 j} \Delta F D I_{\mathrm{t}-I}+\sum_{j=0}^{n} \beta_{a j} \Delta B M V_{\mathrm{t}-j}+\sum_{j=0}^{n} \beta_{4 j} \Delta C P S G_{\mathrm{t}-j} \\
+\sum_{j=0}^{n} \beta_{5 j} \Delta I N F R_{\mathrm{t}-j}+y_{1 j} E C M_{\mathrm{t}-j}+U_{t}
\end{gathered}
$$

A priori expectation: $\beta_{1 j}-\beta_{4 j}>0 ; ; \beta_{5 j}<0 ; \mathbb{Y}_{1 j}<0$

\section{EMPIRICAL RESULTS AND DISCUSSIONS}

\subsection{Unit Root Results}

The unit root tests applied to the logarithm form of each variables as displayed in table 2 reveal that except for foreign direct investment (FDI) and inflation rate (INFR) which are stationary in levels, all other variables attain induced stationarity after first difference using both intercept and intercept with trend.

TABLE 2. UNIT ROOT RESULTS

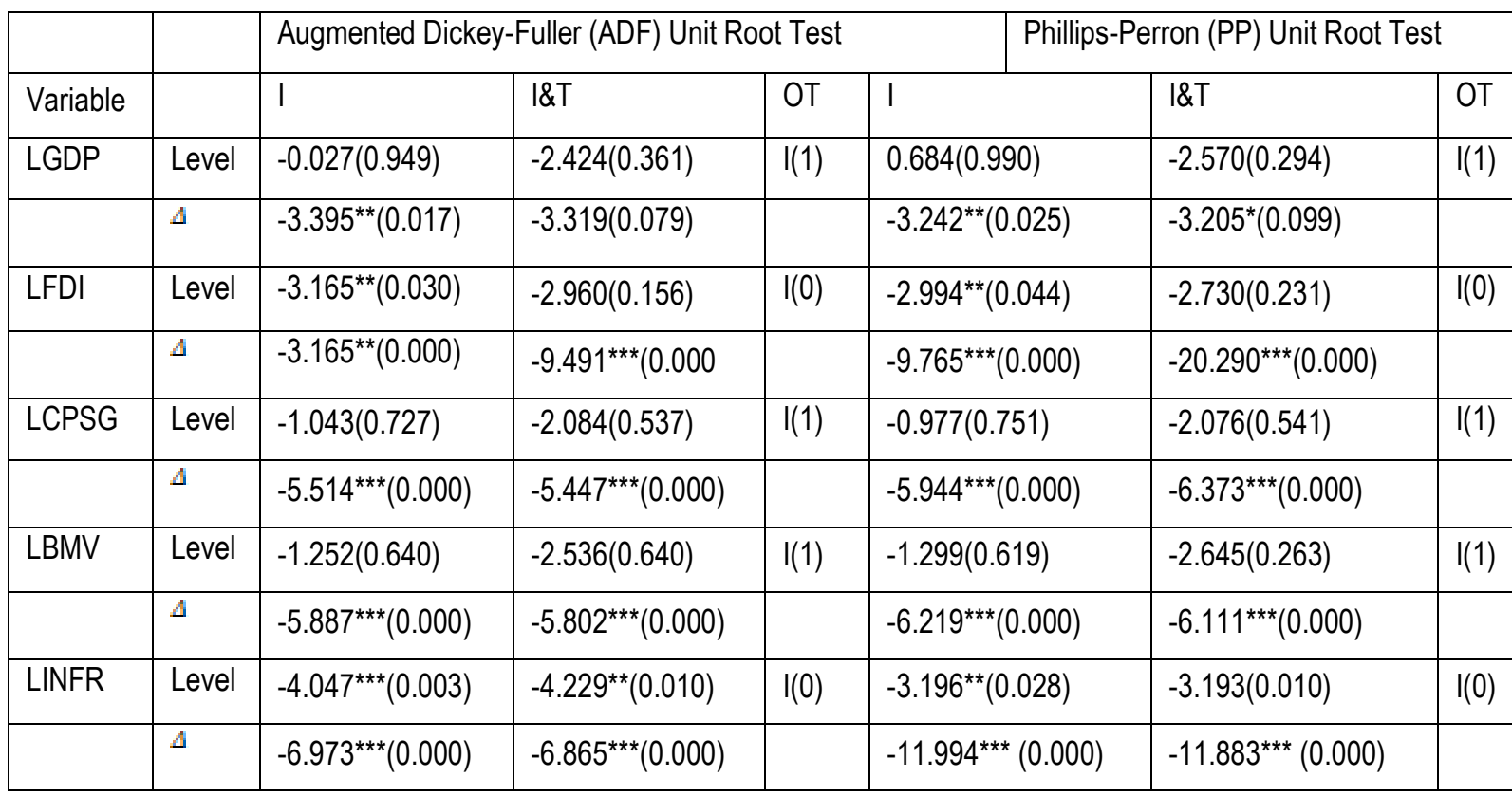

Note: Values in parentheses, p-values; I, intercept; OT, order of integration; $\Delta$, first difference. ${ }^{* \star *},{ }^{* \star},{ }^{*}$ represents significance at $1 \%, 5 \%$ and $10 \%$ respectively.

Source: Author's computation via Eviews 10 
Therefore, since there is a mixed of order of integration of the variables, two variables are I (0) and others are purely I (1), it efficient to apply Autoregressive Distributed lag (ARDL) model in this study.

\subsection{ARDL Bound Cointegration Test Results}

The study tests for cointegration of the variables via the ARDL Bounds test and results shown in table 3. The results show (like similar studies such as Alabi et al. (2018), Yusuf et al. (2020), Adegboyega and Odusanya (2014)), that there is a cointegrating (long-run) relation between FDI, financial deepening (FDEP) and economic growth (GDP) in Nigeria. This implies that the relationship FDI, FDEP and GDP has long term policy implications.

TABLE 3. F-BOUNDS TEST RESULT

\begin{tabular}{|c|c|c|c|c|c|c|}
\hline \multicolumn{4}{|l|}{ Model } & Lag, K, N & F-statistics & Decision \\
\hline \multicolumn{4}{|c|}{$\left(\right.$ LFGDP $\left._{\mathrm{t}} / \mathrm{LFDI}_{\mathrm{t}, \mathrm{LBMV}} \mathrm{LBCPS}_{\mathrm{t}, \mathrm{LINFR}} \mathrm{LCP}_{\mathrm{t}}\right)$} & $(1,4,38)$ & $18.3691^{*}$ & There is cointegration \\
\hline \multirow[t]{2}{*}{ Critical Values } & \multicolumn{2}{|c|}{1 per cent } & \multicolumn{2}{|c|}{5 per cent } & \multicolumn{2}{|l|}{10 per cent } \\
\hline & 3.967 & 5.455 & 2.893 & 4.000 & 2.427 & 3.395 \\
\hline Bounds & $\mathrm{I}(0)$ & $\mathrm{I}(1)$ & $\mathrm{I}(0)$ & $\mathrm{I}(1)$ & $\mathrm{I}(0)$ & $\mathrm{I}(1)$ \\
\hline
\end{tabular}

${ }^{*}$ indicates the rejection of null hypothesis of no levels relationship at $1 \%, 5 \%$ and $10 \%$ levels, when tstatistics is more than critical value at all levels.

Source: Author's computation via Eviews 10

\subsection{Models Estimation}

After establishing a co-integration relationship among the variables, the granger causality test equations, the ARDL long-run model as well as its short run cum error correction model in equations (14), (5) and (6) respectively; to produce the results in tables 5 and 6.

\subsubsection{Pairwise Granger Causality Test Results}

The causality analysis results in table 4 reveal a unidirectional causality running from foreign direct investment (FDI) to economic growth (GDP), implying a partial feedback effect between the two and thus supporting both FDI-growth-led hypothesis and the supply-leading hypothesis of financial development granger-causing growth of an economy. In line with this finding, the null hypothesis of no causality between FDI and economic growth in Nigeria is rejected at the 0.01 level of significance. Thus, the study finds evidence of a causal relationship between FDI and economic growth in Nigeria in the period of study. This finding supports previous studies' (Aderemi et al. (2019); Egbo et al. (2011); Modou and Liu (2017); Safdar (2014)). However, this contradicts the bi-directional causality between 
FDI and GDP found by Kadiatou (2017) and no feedback effect established in Nigeria (by Adeniyi et al. (2012); Okoye and Nwisienyi (2019)).

Likewise, a unidirectional causality runs from economic growth (GDP) to credit to private sector as a ratio of GDP, is also found in this study, unlike Alrabadi and Kharabsheh (2016) who found a bidirectional causality between GDP and CPS in Jordan. This finding led to the rejection of the null hypothesis of no causality between credit to private sector as a ratio of GDP and economic growth in Nigeria at the 0.01 level of significance. Thus, by this finding, this study can go on to assert that a significant causal impact exists between credit to private sector as a ratio of GDP and economic growth in Nigeria.

In the same vein, like Alrabadi and Kharabsheh (2016), this study observes that GDP leads broad money velocity but not vice versa. This signifies a partial feedback effect between GDP and each of the two financial deepening indicators in Nigeria. Therefore, the null hypothesis of no causality between broad money velocity and economic growth in Nigeria, is rejected at the 0.01 level of significance. By this result, it is established in this study that there is significant causality between GDP and broad money velocity in Nigeria.

Generally, this study shows that GDP leads financial deepening in Nigeria over the study period. This finding is similar to other studies (such as Nwakobi et al. (2019); Torruam et al. (2013)). Our findings fail to support supplying leading hypothesis of a unidirectional causality from financial deepening and economic growth, concluded by previous studies (such as Karimo and Ogbonna (2017), Yahaya and Kolapo (2017)). This is not in consonance with Safdar (2014)'s evidence of no causality between financial deepening and economic growth in Pakistan.

Our finding lends credence to the demand-following hypothesis of economic growth stimulating financial development (financial deepening). Finally, there is no causality between inflation and economic growth (GDP), hence any feedback effect between the two variables in Nigeria in the period under study. This is not in line with Safdar (2014)'s submission that inflation causes GDP in Pakistan.

TABLE 4. SUMMARY AND ANALYSIS OF PAIRWISE GRANGER CAUSALITY TEST

\begin{tabular}{|l|l|l|l|}
\hline Variables & Nature of Causality & Significance Level & Effects \\
\hline LFDI and LGDP & Unidirectional & $1 \%$ & Partial feedback effect \\
\hline LGDP and LCPSG & Unidirectional & $1 \%$ & Partial feedback effect \\
\hline LGDP and LBMV & Unidirectional & $1 \%$ & Partial feedback effect \\
\hline LINFR and LGDP & No Causality & $10 \%$ & No feedback effect \\
\hline
\end{tabular}

Source: Author's computation via Eviews 10

\subsubsection{ARDL Models Estimates}

In line with the AIC optimum model selected criteria, the selected model was based on $(1,1,1,0,1)$ lag formation. The results of the long run and short run ARDL model are reported in table 5. 


\section{GROWTH EFFECTS OF FOREIGN DIRECT INVESTMENT AND FINANCIAL DEEPENING IN NIGERIA (1981-2018)}

Table 5 indicates that foreign direct investment (FDI) exerts positive effect on economic growth (GDP) in Nigeria both in the long run and short run. This finding led to the rejection of the null hypothesis that FDI does not have significant positive effect on economic growth in Nigeria. This is due to the fact that the probability values are less than 0.05 . By this result, this study has shown an evidence of positive effect of FDI on economic growth in Nigeria. This finding supports FDI-growth-led hypothesis and aligns with several other similar studies which found evidence of a positive association between FDI and GDP (Adegboye et al. (2020); Adigwe (2015); Aguda and Oladoja (2017); Akanegbu and Chizea (2017); Alabi (2019); Alabi et al. (2018); Dinh et al. (2019); Ek (2017); Jayaraman et al. (2017); Kadiatou (2017); Modou and Liu (2017); Okoye and Nwisienyi (2019); Oniore (2014); Ovat and Amba (2018); Sghaier and Abida(2013); Sharmiladevi (2015); Sokang (2018); Yusuf et al. (2020)). This finding is unlike an evidence of a negative significant as well negative non-significant relation between FDI and GDP shown by some studies (Nsofor and Takon (2017)). In the same vein, this finding is not in agreement with evidence of a short run negative relation (Dinh et al. (2019)) and a positive but insignificant relationship (Adegboyega and Odusanya (2014)) between the FDI and GDP rate.

Moreover, this study indicates that the financial deepening indicator, broad money velocity, has positive significant effect on economic growth in Nigeria in the long run. This supports the results of Nwanna and Chinwudu (2016) as against that of Oniore (2014) showing negative relation between the two variables. This result supports the rejection, at 0.05 level of significance of the null hypothesis that financial deepening indicator-broad money velocity, does not have significant positive effect on economic growth in Nigeria. This implies that in the period of investigation in Nigeria, broad money as a ratio of GDP, has positive effect on economic growth. However, this study confirms the relation between broad money velocity and economic growth to reverse to negative but non-significant in the short run.

In the long run, this study indicates that the financial deepening indicator, credit to private sector as a ratio of GDP has negative non-significant effect on economic growth (GDP) in Nigeria while its influence is absent in the short run model. This is not in line with a priori expectation but is in consonance with previous findings of Onwumere et al. (2012) in Nigeria but against positive and statistically significant effects of CPS on GDP found by Adan (2017) in Kenya; Oniore (2014) in Nigeria; and a negative and non-significant relation found between CPS and GDP in the short run. By this result, the study fails to reject the null hypothesis of no significant positive effect of credit to private sector as a ratio of GDP, on economic growth in Nigeria. Thus, the study can go on to say that credit to private sector as a ratio of GDP does not have significant positive effect on economic growth in Nigeria in the period of study.

Generally, it can be inferred from these results, that financial deepening positively affects economic growth in Nigeria. This finding is in consonance with most previous studies (such as Adan (2017); Efanga et al. (2020); Ghildiyal et al. (2015); Kolawole et al. (2019); Nwanna and Chinwudu (2016); 
Babarinde, G.F.

\section{GROWTH EFFECTS OF FOREIGN DIRECT INVESTMENT AND FINANCIAL DEEPENING IN NIGERIA (1981-2018)}

Sghaier and Abida (2013); Sharmiladevi (2015); Torruam et al (2013); Yusuf et al. (2020)). However, some researches confirm negative relation between financial deepening and economic growth in Nigeria.

Finally, in line with theoretical expectation, this study finds a negative significant association between inflation and economic growth in Nigeria both in the long run and short run. This implies high inflation if not properly checked, can lead to economic retrogression both in the long and short runs in Nigeria.

The long run and short run ARDL model's $\mathrm{R}^{2}$ coefficient of 0.997 and 0.605 generally indicate a strong goodness of fit of the models. In the vein, the DW statistic (1.571) of roughly 2 indicates absence of serial correlation in the models. The overall fitness of the model as indicated by the F-statistic, also indicates a good fit. In the short run, the coefficient of the ECT $(-0.040)$ is negative and significant at $1 \%$ level (0.000). This implies that $4.00 \%$ of the short-run disequilibrium is corrected in the long-run.

TABLE 5. LONG RUN AND SHORT RUN ESTIMATES OF THE ARDL MODEL

\begin{tabular}{|l|l|l|l|}
\hline \multicolumn{2}{|l|}{ Dependent Variable: LGDP/ } \\
\hline \multicolumn{2}{|l|}{ A. ARDL Long run Coefficients } & \multicolumn{2}{l|}{ B. ARDL Short Run and ECM Estimates } \\
\hline LRGDP(-1) & $0.959(0.000)^{* * *}$ & $\Delta($ LFDI) & $0.018(0.0200)^{* *}$ \\
\hline LFDI & $0.018(0.052)^{*}$ & $\Delta($ LBMV) & $-0.016(0.7008)$ \\
\hline LFDI(-1) & $0.023(0.014)^{* *}$ & $\Delta($ LINFR) & $-0.022(0.004)^{* * *}$ \\
\hline LBMV & $-0.016(0.807)$ & ECT & $-0.040(0.000)^{* * *}$ \\
\hline LBMV(-1) & $0.145(0.011)^{* *}$ & & \\
\hline LCPSG & $-0.040(0.358)$ & & \\
\hline LINFR & $-0.022(0.019)^{* *}$ & & \\
\hline LINFR(-1) & $-0.021(0.031)^{* *}$ & & \\
\hline R ${ }^{*}$ & 0.997 & $R^{2}$ & 0.605 \\
\hline Adj. R2 & 0.997 & Adj. R2 & 0.569 \\
\hline Durbin-Watson (D.W.) & 1.571 & D.W. & 1.571 \\
\hline F-statistic & $1540.661^{* * *}(0.000)$ & & \\
\hline
\end{tabular}

Note: Values in parentheses are the p-values; ${ }^{* * *},{ }^{* *},{ }^{*}$ denotes significant at $1 \%, 5 \%$, and $10 \%$ respectively. 


\subsubsection{Post-Estimation Diagnostic Tests}

To ensure the goodness of fit of the model, diagnostic and stability tests are conducted. The tests' results shown in table 6, are the Jarque-Bera (J-B) normality test, Breusch-Godfrey Serial Correlation LM test, Breusch-Pagan-Godfrey heteroscedasticity test, and Ramsey RESET test of model stability.

TABLE 6. POST- ESTIMATION DIAGNOSTIC TESTS

\begin{tabular}{|l|l|l|l|}
\hline Diagnostics & F-statistics & P-value & Decision \\
\hline Normality (Jacque-Berra) & 2.918 & 0.232 & Normality \\
\hline Serial Correlation LM(Breusch-Godfrey) & 1.669 & 0.207 & No serial correlation \\
\hline Heteroscedasticity (Breusch-Pagan-Godfrey) & 1.110 & 0.385 & Homoscedasticity \\
\hline Stability (Ramsey RESET) & 1.444 & 0.239 & Stability \\
\hline
\end{tabular}

Source: Author's computation via Eviews 10

Specifically, in table 6, the J-B statistic (2.918) with the p-value of $(0.232)$ greater than even $10 \%$, implies that the standardized residuals are normally distributed. The skewness statistic $(0.400)$ of approximately zero ( 0 ) also corroborates the normality result.

As per table 6 , the serial correlation LM test's F-statistic value of 1.669 , with a p-value $(0.207)$ not less than or equal to 10 per cent significant level validated non-rejection of the null hypothesis of serial correlation. Hence, the ARDL model does not suffer auto-correlation problem.

The heteroscedasticity diagnostic via the Breusch-Pagan-Godfrey test, with the F-stat. (1.110) reported in table 6 with a p-value $(0.385)$ greater than 10 per cent threshold of significance level. This implies validation of the null hypothesis of no presence of heteroscedasticity in the residual of the model.

The ARDL model was found to be stable given its Ramsey RESET test (1.444), with a p-value (0.239) not less than or equal to $10 \%$. This implies that the null hypothesis of all coefficients in the given regression is stable cannot be rejected. Furthermore, the cumulative sum of recursive residuals (CUSUM) stability test plot in figure 1 suggests that the model appears stable and correctly specified given that the plot of the CUSUM test do not exceed the bounds of the 5 percent level of significance.

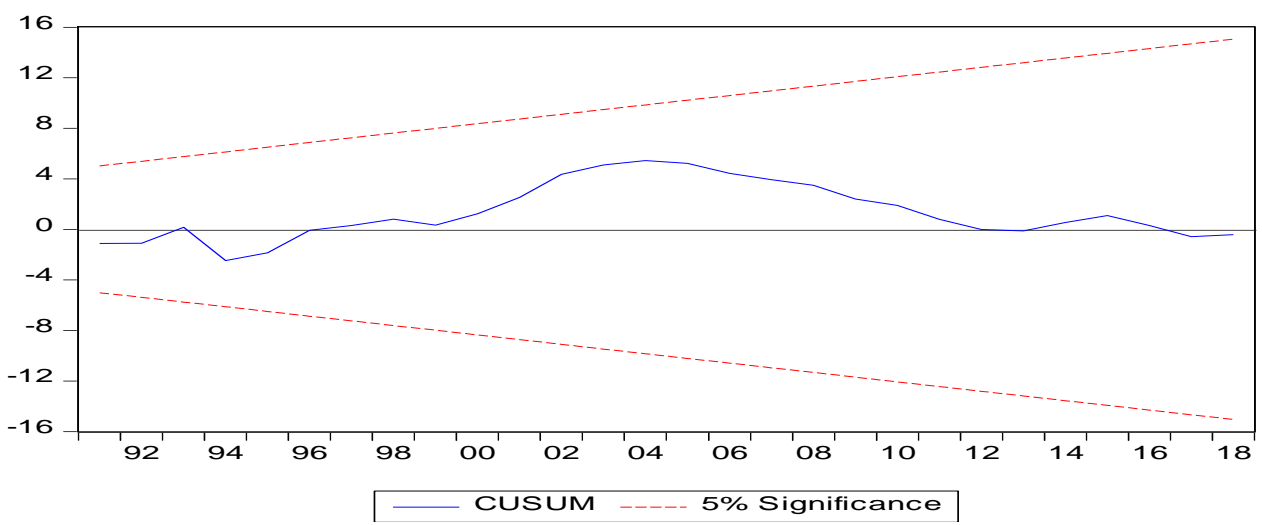

FIGURE 1. PLOT OF CUMULATIVE SUM(CUSUM) OF RECURSIVE RESIDUALS

Source: Author's design using Eviews 10 


\section{CONCLUSION}

This paper examines the causal relationship and effect of foreign direct investment and financial deepening on economic growth of Nigeria (1981-2018) by employing pairwise granger causality test, and ARDL model. A long-run relationship was established between financial deepening indicators, foreign direct investment and economic growth in Nigeria. The results suggest that foreign direct investment (FDI) is positively related with economic growth (GDP) in Nigeria both in the long run and short run. The financial deepening indicator, broad money velocity has positive significant effect on economic growth in Nigeria in the long run but the position is reversed to negative non-significant in the short run. In the long run, the financial deepening indicator, credit to private sector as a ratio of GDP, has a negative non-significant effect on economic growth (GDP) in Nigeria while its influence is absent in the short run model. Also found is a negative significant relationship between inflation and economic growth (GDP) in Nigeria both in the long run and short run.

Furthermore, also shown by this study is a unidirectional causality running from foreign direct investment (FDI) to economic growth (GDP), implying a partial feedback effect between the two and supporting the supply-leading hypothesis. Likewise, unidirectional causality flows from economic growth (GDP) to each of the two financial deepening indicators; credit to private sector as a ratio of GDP, and broad money velocity. This implies that economic growth (GDP) leads financial deepening in Nigeria over the study period. This finding lends credence to the demand-following hypothesis of economic growth stimulating financial development (financial deepening).

It can therefore be concluded that foreign direct investment and financial deepening have positive on economic growth in Nigeria with causality flowing from foreign direct investment to economic growth and the latter granger-causing financial deepening in Nigeria. This implies that both financial deepening and foreign direct investment are determinants of economic growth in Nigeria.

To boost economic growth in Nigeria, it is recommended that government should implement policies to stimulate FDI inflows to the country. Likewise, greater financial deepening, like increase in access to private credits and more liquidity should be encouraged by the government. In the same vein, development of financial institutions (banks, and others) as well as financial markets (money market and capital market) should be a top policy priority of the government to as to ensure the financial sector is developed the more and deepened further to enable the sector impact the Nigeria's economy positively. All these policies should be embedded in a stable macroeconomic environment devoid of investmentsuppressing inflation. 


\section{GROWTH EFFECTS OF FOREIGN DIRECT INVESTMENT AND FINANCIAL DEEPENING IN NIGERIA (1981-2018)}

\section{REFERENCES}

Adan, I. R. (2017). The relationship between financial deepening and economic growth in Kenya. MBA project, University of Nairobi.

Adegboyega, S. B., \& Odusanya, I. A. (2014). Empirical analysis of trade openness, capital formation, FDI, and economic growth: Nigeria experience. The International Journal of Social Sciences and Humanities Invention, 1(1): 36-50.

Adegboyega, S.B., Odusanya, I.A. (2014). Financial Sector Development and Economic Growth: The Nigeria Experience. Scholarly Journal of Business Administration, 4(5): 124-131.

Adegboye, F. B., Osabohien, R., Olokoyo, F. O., Matthew, O., \& Adediran, O. (2020). Institutional quality, foreign direct investment, and economic development in sub-saharan Africa. Humanities and social sciences communications, 7(38): 1-9. https://doi.org/10.1057/s41599-020-0529-x

Adeleke, K. M., Olowe, S.O. \& Fasesin, O. O. (2014). Effect of foreign direct investment on Nigeria economic growth. International Journal of Academic Research in Business and Social Sciences, 4(8): 234-242. DOI: 10.6007/JJARBSS/v4-i8/1092

Adeniyi, O., \& Ajide, B., \& Salisu, A. (2015). Foreign capital flows, financial development and growth in sub-saharan Arica. Journal of Economic Development, 40(3): 85-103.

Adeniyi, O., Omisakin, O., Egwaikhide, F. O., \& Oyinlola, A. (2012). Foreign direct investment, economic growth and financial sector development in small open developing economies. Economic Analysis and Policy, 42(1): 105-127.

Aderemi, T. A., Olayemi, H. O., Adejumo, A. V., \& Yusuff, F. A. (2019). Panel cointegration and granger causality approach to foreign direct investment and economic growth in some selected emerging economies. European Financial and Accounting Journal, 14(2): 27-42.

Adigwe P. K., Ezeagba, C. E., \& Udeh, F. N. P. (2015). Effect of foreign direct investment on Nigerian economic growth. European Journal of Research and Reflection in Management Sciences, 3(5): 2834.

Aguda, N. A., \& Oladoja, I. (2017). The effect of foreign direct investment on economic growth in Nigeria. International Journal of Business \& Law Research, 5(1): 52-60.

Akanegbu, B. N. \& Chizea, J. J. (2017). Foreign direct investment and economic growth in Nigeria: an empirical analysis. European Journal of Research in Social Sciences, 5(1): 11-20.

Akiri, S.E., Vehe, B. M., \& ljuo, O. A. (2016). Foreign direct investment and economic growth in Nigeria: An empirical investigation. IIARD International Journal of Economics and Business Management, 2(5): 55-66.

Alabi, K. O. (2019). The effect of foreign direct investment on economic growth: Nigeria experience. Open Journal of Applied Sciences, 9, 372-385.DOI: 10.4236/ojapps.2019.95031

Alabi, M. O., Tella, S. A., Odusanya, I. A., \& Yinusa, O. G. (2018). Financial deepening, foreign direct investment and output performance in Nigeria. Scientific Annals of Economics and Business, 65(2): 193-204. DOI: 10.2478/saeb-2018-0007

Alenoghena, R. O. (2014). Capital market, financial deepening and Nigeria's economic growth: Cointegration and error correction model approach. Global Journal of Commerce and Management Perspective, 3(3):18-26.

Ayanwale, A. B. (2007). FDI and economic growth: Evidence from Nigeria. AERC research paper 165, African Economic Research Consortium, Nairobi. 


\section{GROWTH EFFECTS OF FOREIGN DIRECT INVESTMENT AND FINANCIAL DEEPENING IN NIGERIA (1981-2018)}

Alabi, T.M., ljigah, E.A., Saka, A. (2018). Appraisal of project scheduling in Nigeria construction industry: A case study of Ibadan, Nigeria. International Journal of Research, 5(19): 851-860.

Alfaro, L., Chanda, A., Kalemli-Ozcan, S., \& Sayek, S. (2007). How does foreign direct investment promote economic growth? Exploring the effects of financial markets on linkages. Working paper 12522. National bureau of economic research. http://www.nber.org/papers/w12522

Alrabadi, D. W. H., \& Kharabsheh, B. A. (2016). Financial deepening and economic growth: The case of Jordan. Journal of Accounting and Finance, 16(6): 158-166.

Asogwa, F.O., \& Manasseh, C. O. (2014). The effect of foreign direct investment on economic growth in Nigeria. IOSR Journal of Economics and Finance, 3(5): 37-45.

Awolusi, O. D., \& Adeyeye, O. P. (2016). Effect of foreign direct investment on economic growth in Africa. Problems and Perspectives in Management, 14(2-2): 289-297. DOI:10.21511/ppm.14(22). 2016.04

Chang, S., \& Wu, C. (2012). The relationship between financial deepening and economic growth in Taiwan. Business, Economics, and Financial Science Management., AISC 143, 205-210.

Chigbu, E. E., Ubah C. P., \& Chigbu U. S. (2015). Effect of capital inflows on economic growth of developing countries. International Journal of Management Science and Business Administration, 1(7): 7-21.

Dinh, T. T., Vo, D. H., Vo, A. T., \& Nguyen, T. C. (2019). Foreign direct Investment and economic growth in the short run and long run: Empirical evidence from developing countries. Journal of Risk and Financial Management, 12(1): 176-186.

Efanga, U. O., Ogochukwu, C. O., \& Ugwuanyi, G. O. (2020). The effect of financial deepening on the economy of Nigeria (1981-2018). Asian Journal of Economics, Business and Accounting, 15(1): 1221. DOI: $10.9734 / A J E B A / 2020 / v 15 i 130204$

Egbo, O.P., Onwumere, J. U. J., Okpara, G. C. (2011). Foreign direct investment and economic growth in Nigeria: A granger causality analysis. International Journal of Current Research, 3(11): 225-232.

Ek, A. (2007). The effect of FDI on economic growth: The case of China (Bachelor thesis). Jönköping International Business School, Jönköping University, Jönköping.

Gezer, M. A. (2018). The relationship between financial deepening and economic growth: Bootstrap causality approach for the selected upper middle income countries. Theoretical and Applied Economics, 25(1): 95-112.

Ghildiyal, V., Pokhriyal, A. K., \& Mohan, A. (2015). Effect of financial deepening on economic growth in indian perspective: ardl bound testing approach to cointegration. Asian Development Policy Review, 3(3): 49-60. DOI: 10.18488/journal.107/2015.3.3/107.3.49.60.

Jayaraman, S., Fausey, C.M., Smith, L.B. (2015). The faces in infant-perspective scenes change over the first year of life. PLoS One, 10(5): 1-16.

Karimo, T.M., Ogbonna, O.E. (2017). Financial Deepening and Economic Growth Nexus in Nigeria: Supply-Leading or Demand-Following? Economies, 5(1): 1-18.

Nsofor, E.S., Takon, S.M., Ugwuegbe, S.U. (2017). Modeling Exchange Rate Volatility and Economic Growth in Nigeria. Noble International Journal of Economics and Financial Research, 2(6): 88-97.

Nwaolisa, E.F., Cyril, U.M. (2018). Assessment of Financial Deepening on The Growth of Nigerian Economy: 1990-2016. International Journal of Academic Management Science Research (IJAMSR), 2(11): 70-82. 
Okoye, O.V., Nwisienyi, K.J. (2019). Foreign Direct Investment and Economic Growth in Nigeria: A Johansen Co-Integration Approach. International Journal of Research and Innovation in Social Science (IJRISS), 3(10): 15-21.

Okumoko, T.P., Akarara, E.A., Opuofoni, C.A. (2018). Impact of Foreign Direct Investment on Economic Growth in Nigeria. International Journal of Humanities and Social Science, 8(1): 170-176.

Oniore, J. (2014). Impact of financial deepening and foreign direct investment effectiveness on economic growth in Nigeria. International Journal of Economics, Commerce and Management, 2(10): 1-16.

Ovat, O.O., Antakikam, A.E. (2018). Foreign Direct Investment And Economic Growth In Developing Countries: How Has Nigeria Fared?. International Journal of Humanities and Social Science, 9(5): 55-63.

Safdar, H.T. (2014). Impact of GDP Growth Rate on Poverty of Pakistan: A quantitative approach. EuroAsian Journal of Economics and Finance, 2(2): 119-126.

Sghaier, I.M., Abida, Z. (2013). Foreign Direct Investment, Financial Development and Economic Growth: Empirical Evidence from North African Countries. Journal of International and Global Economic Studies, 6(1): 1-13.

Sharmiladevi, J.C. (2017). Financial Deepening, Foreign Direct Investment and Economic Growth. Asian Journal of Management Research, 6(1): 277-283.

Sokang, K. (2018). The Impact of Foreign Direct Investment on the Economic Growth in Cambodia: Empirical Evidence. International Journal of Innovation and Economic Development, 4(5): 31-38.

Torruam, J.T., Chiawa, M.A., Abur, C.C. (2013). Financial deepening and economic growth in Nigeria: an application of co-integration and causality analysis. 3rd International Conference on Intelligent Computational Systems, April 29-30, Singapore. 